\title{
The Use of 25-hydroxyvitamin D Saliva Test to Replace Vitamin D Serum Blood Test in Healthy People
}

\author{
Dina Keumala Sari ${ }^{1 *}$, Liza Meutia Sari ${ }^{2}$, Lidya Imelda Laksmi ${ }^{3}$, Farhat Farhat ${ }^{4}$ \\ ${ }^{1}$ Tropical Medicine Program Study, Faculty of Medicine, Universitas Sumatera Utara, Medan, Indonesia; ${ }^{2}$ Department of Oral \\ Medicine, Faculty of Dentistry, Universitas Syiah Kuala, Banda Aceh, Indonesia; ${ }^{3}$ Department of Anatomy Pathology, Faculty \\ of Medicine, Universitas Sumatera Utara, Medan, Indonesia; ${ }^{4}$ Department of Ear, Nose, Throat, Head, and Neck, Faculty of \\ Medicine, Universitas Sumatera Utara, Medan, Indonesia
}

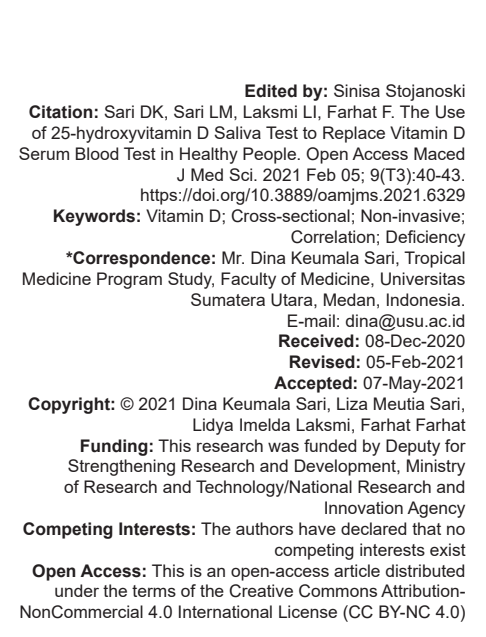

\begin{abstract}
BACKGROUND: Routine examination of Vitamin D levels is carried out by checking serum 25-hydroxyvitamin D $(25[\mathrm{OH}] \mathrm{D})$ levels which indicate circulating Vitamin $\mathrm{D}$ levels. While serum 1.25(OH)D levels are less frequently performed, although serum 1.25(OH)D levels represent the active form of Vitamin D be a substitute for checking Vitamin D levels.

AIMS: This study aims to see the correlation between Vitamin D levels, namely, 25(OH)D and 1.25(OH)D saliva which correlate with serum $25(\mathrm{OH}) \mathrm{D}$ and $1.25(\mathrm{OH}) \mathrm{D}$ levels so that the examination of salivary Vitamin $\mathrm{D}$ levels can be a substitute for checking serum Vitamin D levels.

MATERIAL AND METHODS: This study is a cross-sectional study involving healthy men and women, aged 20-50 years, sampling in Lima Puluh Village, Batubara District, North Sumatra Province, Indonesia. The parameters studied were $25(\mathrm{OH}) \mathrm{D}$ and $1.25(\mathrm{OH}) \mathrm{D}$ levels of saliva and serum.

RESULTS: This study involved 56 study subjects, male and female, with a percentage of deficiencies of $78.6 \%$ by examining $25(\mathrm{OH}) \mathrm{D}$ saliva and $76.8 \%$ by examining $25(\mathrm{OH}) \mathrm{D}$ serum. As for the $1.25(\mathrm{OH}) \mathrm{D}$ examination of saliva and serum, all were within normal limits. The analysis showed that a moderate correlation was obtained for levels of $25(\mathrm{OH}) \mathrm{D}$ saliva with serum $25(\mathrm{OH}) \mathrm{D}(\mathrm{p}=0.424)$ and a weak correlation for levels of $1.25(\mathrm{OH}) \mathrm{D}$ saliva with serum $25(\mathrm{OH}) \mathrm{D}(\mathrm{p}=0.339)$
\end{abstract}

CONCLUSIONS: Salivary $25(\mathrm{OH}) \mathrm{D}$ assay can be used to replace serum $25(\mathrm{OH}) \mathrm{D}$ assay in healthy people as a non-invasive alternative.

\section{Introduction}

Vitamin D deficiency occurs in various parts of the world including in the tropics and occurs in healthy and sick people [1], [2]. Examination of serum 25-hydroxyvitamin D $(25[\mathrm{OH}] \mathrm{D})$ levels is needed to determine the level of Vitamin $\mathrm{D}$ in the circulation and the active form, namely $1.25(\mathrm{OH})$ D serum [3]. However, this examination often causes discomfort in the patient so that an easier examination is needed and the patient does not feel pain.

This examination of Vitamin D is very necessary due to the role of Vitamin $D$ which can increase body immunity, through its role as an endocrine [4], [5], [6], [7]. The role of Vitamin $D$ in this is as an anti-inflammatory and regulatory effect on the immune system. The effects of Vitamin $D$ therapy can be felt in various metabolic diseases and cancer [7], [8].

Examination of Vitamin $D$ levels in the form of $25(\mathrm{OH}) \mathrm{D}$ and $1.25(\mathrm{OH}) \mathrm{D}$ in saliva has not been used often for diagnostic purposes of Vitamin $D$ levels because these levels may not show the actual levels in the body [9].
Saliva examination is more focused on hormonal, immunological, and infection tests, but it is rarely used [10], [11]. In addition, the saliva examination may reveal many other contamination factors, so that saliva examination in diagnostic tests is often neglected [11]. However, if done according to the procedure, then the possibility of contaminants can be removed.

Based on the results of the above research, it is desirable to conduct a study that looks at the correlation between levels of 25(OH)D and 1.25(OH)D of saliva and serum. The goal is to find an alternative replacement for serum testing that is invasive and gives discomfort to the patient. It is hoped that with this examination, saliva examination can replace serum testing.

\section{Methods}

This research was conducted after following the ethics committee protocol and was approved by 
the ethics committee of the Universitas Sumatera Utara with number 63/KEP/USU/2020. The subjects of this study had also signed informed consents before being included in this study. During the study, no therapy or intervention was carried out and the research subject was not charged any fees for the laboratory examination.

This research was conducted in Lima Puluh Village, Batubara District, Simalungun Regency, North Sumatra, Indonesia. This area is about $153 \mathrm{~km}$ from the city center, namely, Medan City, with the location of rubber and oil palm plantations in the hope that the research subjects will be healthier in their activities. This study included 56 study subjects with inclusion criteria were men and women aged 18-60 years, not currently experiencing chronic pain, kidney problems, liver problems, or other hormone disorders. Exclusion criteria were study subjects who consumed Vitamin D supplements regularly, were pregnant, and were breastfeeding.

The tests carried out were examination of $25(\mathrm{OH}) \mathrm{D}$ and $1.25(\mathrm{OH}) \mathrm{D}$ levels of serum and saliva, examination of demographic data, and other anthropomentries. The examination was carried out by taking $5 \mathrm{~mL}$ of blood and $2 \mathrm{~mL}$ of saliva and then checking the serum and saliva levels of 25(OH)D and 1.25(OH)D. Before the examination, research subjects were asked not to consume food and drinks for at least $90 \mathrm{~min}$ before being examined. Furthermore, centrifugation is carried out (2500 g/10 min) and immediately stored at $-20^{\circ} \mathrm{C}$, as well as in the serum examination, after blood is drawn, centrifugation is carried out and stored at $-20^{\circ} \mathrm{C}$ for further determination of the levels of $25(\mathrm{OH}) \mathrm{D}$ and $1.25(\mathrm{OH}) \mathrm{D}$ saliva.

Serum and salivary $25(\mathrm{OH}) \mathrm{D}$ level category are defined as deficiency if $10 \mathrm{ng} / \mathrm{mL}$, including insufficiency if $11-20 \mathrm{ng} / \mathrm{mL}$, and including optimal if $\geq 20 \mathrm{ng} / \mathrm{mL}$ category $1.25(\mathrm{OH}) \mathrm{D}$ serum and saliva are deemed deficient if $\leq 48 \mathrm{pmol} / \mathrm{L}$ and normal if $>48 \mathrm{pmol} / \mathrm{L}$ [12], [13]. Examination of 25(OH)D and $1.25(\mathrm{OH}) \mathrm{D}$ serum and saliva was carried out using the Bio-Rad enzyme-linked immunosorbent assay (ELISA) technology tool, California, United States of America, using the ELISA kit, Brand Bioassay, Bioassay Technology Laboratory, Shanghai, China.

Statistical analysis is performed by presenting the data in the form of standard deviations if the data are normally distributed, but if the data are not normally distributed, then it is presented in the form of a minimum, maximum, and median. For correlation analysis with normal distribution, the Pearson correlation test will be used, whereas if the data are not normally distributed, the Spearman correlation test will be used. The strength of correlation is $0.2 \leq 0.4$, which means that the correlation is weak, $0.4 \leq 0.6$ is stated as moderate correlation, and $0.6 \leq 0.8$ is stated as strong.

\section{Results}

Based on demographic data, it can be seen that in the research location there are more productive ages, namely, in their mid-30s, and some of the female group work more as housewives, while the male group is self-employed (Table 1). Based on anthropometric examination, it showed that most of the study subjects were categorized as obese; however, based on the criteria for abdominal circumference, a greater percentage of women experienced central obesity (Table 2).

TablesTable 1: Characteristic of the subjects

\begin{tabular}{lll}
\hline Parameters of sociodemographic & Mean & $\mathrm{n}(\%)$ \\
\hline Age (years) & $\begin{array}{l}41.32 \pm 10.68 \\
\text { Minimum: } 18 \\
\text { Maximum: } 58 \\
\text { Median: } 42\end{array}$ \\
Age classification & & \\
$18-25$ years & & \\
$26-35$ years & $7(12.5)$ \\
$36-45$ years & $6(10.7)$ \\
$46-60$ years & $19(33.9)$ \\
Genders & $24(42.9)$ \\
Male & \\
Female & $23(41.1)$ \\
Ethnic & $33(58.9)$ \\
Batak & \\
Melayu & $26(46.4)$ \\
Occupation & $30(53.6)$ \\
Housewife & \\
Intrepreneur & $21(37.5)$ \\
State civil apparatus & $14(25)$ \\
Farmer & $9(16)$ \\
Student & $8(14.3)$ \\
Education & $4(7.2)$ \\
Strata 1 & \\
Diploma & $9(16.1)$ \\
Senior high school & $2(3.6)$ \\
Junior high school & $33(58.9)$ \\
Primary school & $8(14.3)$ \\
Vitamin D supplementation & $4(7.1)$ \\
No & \\
Yes & $56(100)$ \\
\hline Continues variable: Mean $\pm S D$, Categorical variable: $\mathrm{n}(\%)$, SD: Standard deviation. & \\
& & $0(0)$ \\
\hline
\end{tabular}

Table 3 shows that the percentage of deficiencies is $78.6 \%$ by testing $25(\mathrm{OH}) \mathrm{D}$ saliva and $76.8 \%$ by testing serum $25(\mathrm{OH}) \mathrm{D}$. As for the $1.25(\mathrm{OH})$ $\mathrm{D}$ examination of saliva and serum, it was shown that $100 \%$ of the study subjects were within normal limits.

Table 2: Anthropometry parameters of the subjects

\begin{tabular}{|c|c|c|}
\hline Variable & Mean & $\mathrm{n}(\%)$ \\
\hline \multirow[t]{4}{*}{ Body mass index (BMI) $\left(\mathrm{kg} / \mathrm{m}^{2}\right)$} & $26.71 \pm 11.76$ & \\
\hline & Minimum: 16.69 & \\
\hline & Maximum: 88.95 & \\
\hline & Median: 24.62 & \\
\hline \multicolumn{3}{|l|}{ BMI classification } \\
\hline$<18 \mathrm{~kg} / \mathrm{m}^{2}$ & & $3(5.4)$ \\
\hline $18-22.9 \mathrm{~kg} / \mathrm{m}^{2}$ & & $17(30.4)$ \\
\hline $23-24.9 \mathrm{~kg} / \mathrm{m}^{2}$ & & $11(19.6)$ \\
\hline$>25 \mathrm{~kg} / \mathrm{m}^{2}$ & & $25(44.6)$ \\
\hline \multicolumn{3}{|c|}{ Waist circumference measurement and classification } \\
\hline Men $(\mathrm{cm})$ & $83.57 \pm 11.07$ & $16(69.6)$ \\
\hline$<90 \mathrm{~cm}$ & & $7(30.4)$ \\
\hline \multicolumn{3}{|l|}{$>90 \mathrm{~cm}$} \\
\hline Women $(\mathrm{cm})$ & $82.36 \pm 12.14$ & $13(39.4)$ \\
\hline$<80 \mathrm{~cm}$ & & $20(60.6)$ \\
\hline$>80 \mathrm{~cm}$ & & \\
\hline
\end{tabular}

The results of the study in Table 4 show that there is a moderate correlation for levels of $25(\mathrm{OH})$ $D$ saliva with $25(\mathrm{OH}) \mathrm{D}$ serum $(p=0.424)$ and a weak correlation for levels of $1.25(\mathrm{OH}) \mathrm{D}$ saliva with $25(\mathrm{OH}) \mathrm{D}$ serum $(p=0.339)$ using the Spearman test. 
Table 3: Vitamin D saliva and serum level

\begin{tabular}{lll}
\hline Variable & Saliva & Serum \\
\hline $25(\mathrm{OH}) \mathrm{D}$ level $(\mathrm{ng} / \mathrm{mL})$ & $16.54 \pm 5.01$ & $15.07 \pm 15.34$ \\
& $\begin{array}{l}\text { Minimum: } 2.05 \\
\text { Maximum: } 25.1\end{array}$ & Minimum: 2.32 \\
& Median: 17.45 & Meximum: 80.1 \\
& & \\
$25(\mathrm{OH}) \mathrm{D}$ categorized $\mathrm{n}(\%)$ & $6(10.7)$ & $30(53.6)$ \\
$\leq 10 \mathrm{ng} / \mathrm{mL}$ (Deficiency) & $38(67.9)$ & $13(23.2)$ \\
$11-20 \mathrm{ng} / \mathrm{mL}$ (Insufficiency) & $12(21.4)$ & $13(23.2)$ \\
$\geq 20 \mathrm{ng} / \mathrm{mL}($ Optimal) & $201.15 \pm 50.58$ & $268.31 \pm 219.26$ \\
$1.25(\mathrm{OH}) \mathrm{D}$ level (pmol/L) & Minimum: 52.7 & Minimum: 51.7 \\
& Maximum: 285 & Maximum: 884.2 \\
& Median: 221.5 & Median: 182 \\
$1.25(\mathrm{OH})$ D categorized $\mathrm{n}(\%)$ & & \\
$\leq 48 \mathrm{pmol} / \mathrm{L}$ (Deficiency) & $0(0)$ & $0(0)$ \\
$>48 \mathrm{pmol} / \mathrm{L}$ (Normal) & $56(100)$ & $56(100)$ \\
\hline
\end{tabular}

\section{Discussion}

This study shows that it appears that the occurrence of Vitamin D deficiencies still occurs in a group of healthy research subjects, although not accompanied by diseases caused by Vitamin $D$ deficiency [1], [14]. Examination of Vitamin D has become a routine examination performed, and most often uses serum [3], [15], [16]. This examination is often uncomfortable and invasive. Various studies have also been conducted to compare the examination with other body fluids [17], [18].

Table 4: Correlation between Vitamin $D$ saliva and serum level

\begin{tabular}{lll}
\hline Variable & $\begin{array}{l}25(\mathrm{OH}) \mathrm{D} \text { level }(\mathrm{ng} / \mathrm{mL}) \\
\text { in serum }\end{array}$ & $\begin{array}{l}1.25(\mathrm{OH}) \mathrm{D} \text { level } \\
(\mathrm{pmol} / \mathrm{L}) \text { in serum }\end{array}$ \\
\hline $\begin{array}{l}\mathrm{r}=0.424 \text { (positive-moderate) } \\
(\mathrm{ng} / \mathrm{mL}) \text { in saliva }\end{array}$ & $\mathrm{p}=0.001$ (significant) \\
& $\mathrm{n}=56$ & \\
$1.25(\mathrm{OH}) \mathrm{D}$ & & $\mathrm{r}=0.339$ (positive-weak) \\
(pmol/L) in saliva & & $\mathrm{p}=0.01$ (significant) \\
& & $\mathrm{n}=56$
\end{tabular}

In addition to serum examinations, there are studies that discuss the diagnosis of Vitamin D status using a questionnaire [19]. This study suggests that an invasive examination is not required to establish vitamin status, but this study focuses on the elderly [19]. Other studies have shown that serum levels show more precise results compared to other body fluids [20], [21], [22].

The saliva examination in this study showed a higher level than the serum level, but this examination is probably due to the different sensitivity in detecting $25(\mathrm{OH}) \mathrm{D}$ in serum and saliva. Saliva examination is also considered to be heavily influenced by contaminants so that these results cannot be adjusted to the level in serum. However, this study showed that there was a moderate correlation between saliva and serum levels, especially at $25(\mathrm{OH}) \mathrm{D}$ levels.

Where on the examination of $1.25(\mathrm{OH}) \mathrm{D}$ serum showed a higher limit compared to serum, so that with a cutoff point of $48 \mathrm{pmol} / \mathrm{L}$, it showed that no study subjects had Vitamin $D$ deficiency. All study subjects belonged to the normal group. This result is certainly different from other studies, which showed a deficiency both through serum and saliva [2], [5], [17],
[22], [23], [24].

This study shows a moderate strength of correlation between saliva and serum for $25(\mathrm{OH}) \mathrm{D}$ levels, so this moderate correlation is expected to show that the saliva assessment can be used as the same test as the test on serum. Examination 1.25(OH)D showed a weak correlation, this needs further analysis, and indicates that salivary examination cannot reveal the correlation between saliva and serum.

This study also has limitations, namely, this study has abnormal data with Vitamin D levels that have very high and very low values, this study also does not assess the levels of calcium and parathyroid hormone which can describe the effect between the three nutrients, and this study did not compare with Vitamin D levels in people with the disease which would have shown a more pronounced difference.

\section{Conclusions}

Salivary 25(OH)D assay can be used to replace serum $25(\mathrm{OH}) \mathrm{D}$ assay in healthy people as a non-invasive alternative. Examination using saliva as a substitute for serum testing is expected to facilitate the examination of $25(\mathrm{OH}) \mathrm{D}$.

\section{Acknowledgment}

The authors gratefully acknowledge that the present research funded by Deputy for Strengthening Research and Development, Ministry of Research and Technology/National Research and Innovation Agency for the 2020 Fiscal Year in accordance with the Research Contract Amendment Number: 11/AMD/E1/ KP.PTNBH/2020, dated May 11, 2020.

\section{References}

1. Sari DK, Mega JY, Harahap J. Nutrition status related to clinica improvement in AFB-positive pulmonary tuberculosis patients in primary health centres in Medan, Indonesia. Open Access Maced J Med Sci. 2019;7(10):1621-7. https://doi.org/10.3889/ oamjms.2019.338

2. Chaiprasongsuk A, Janjetovic Z, Kim TK, Jarrett SG, D'Orazio JA, Holick MF, et al. Protective effects of novel derivatives of Vitamin D3 and lumisterol against UVB-induced damage in human keratinocytes involve activation of Nrf2 and p53 defense mechanisms. Redox Biol. 2019;24:101206. https:// doi.org/10.1016/j.redox.2019.101206

PMid:31039479 
3. Alshahrani FM, Almalki MH, Aljohani N, Alzahrani A, Alsaleh Y, Holick MF. Vitamin D: Light side and best time of sunshine in Riyadh, Saudi Arabia. Dermatoendocrinol. 2013;5(1):177-80. https://doi.org/10.4161/derm.23351

PMid:24494051

4. Ganmaa D, Munkhzul B, Fawzi W, Spiegelman D, Willett WC, Bayasgalan P, et al. High-dose Vitamin D3 during tuberculosis treatment in Mongolia. A randomized controlled trial. Am J Respir Crit Care Med. 2017;196(5):628-37. https://doi.org/10.1164/ rccm.201705-0936oc

PMid:28692301

5. McCullough PJ, Lehrer DS. Vitamin D, cod liver oil, sunshine, and phototherapy: Safe, effective and forgotten tools for treating and curing tuberculosis infections a comprehensive review. J Steroid Biochem Mol Biol. 2018;177:21-9. https://doi. org/10.1016/j.jsbmb.2017.07.027

PMid:28756294

6. Wahyunitisari MR, Mertaniasih NM, Amin M, Artama WT, Koendhori KB. Vitamin D, cell death pathways, and tuberculosis. Int J Mycobacteriol. 2017;6(4):349-55. https://doi.org/10.4103/ ijmy.ijmy_120_17 PMid:29171448

7. Bochen F, Balensiefer B, Körner S, Bittenbring JT, Neumann F, Koch $A$, et al. Vitamin $D$ deficiency in head and neck cancer patients - prevalence, prognostic value and impact on immune function. Oncoimmunology. 2018;7(9):e1476817. https://doi.org /10.1080/2162402x.2018.1476817

PMid:30228945

8. Fanidi A, Muller DC, Midttun O, Ueland PM, Vollset SE, Relton C Vineis $P$, et al. Circulating Vitamin $D$ in relation to cancer incidence and survival of the head and neck and oesophagus in the EPIC cohort. Sci Rep. 2016;6:36017.

PMid:27812016

9. Fairney A, Saphier PW. Studies on the measurement of 25-hydroxy Vitamin D in human saliva. Br J Nutr. 1987;57(1):1325. https://doi.org/10.1079/bjn19870005 PMid:3801379

10. Gottlieb CW, Retief FP, Herbert V. Blockade of Vitamin B12binding sites in gastric juice, serum and saliva by analogues and derivatives of Vitamin B12 and by antibody to intrinsic factor. Biochim Biophys Acta. 1967;141(3):560-72. https://doi. org/10.1016/0304-4165(67)90185-7 PMid:5233398

11. Flusser J, Chvojkova V, Kozicka V. [Relationship between saliva and Vitamin B12. (Contribution to the problem of the intrinsic factor)]. Cas Lek Cesk. 1961;100:199-205.

PMid:13700414

12. Heaney RP, Holick MF. Why the IOM recommendations for Vitamin D are deficient. J Bone Miner Res. 2011;26(3):455-7. https://doi.org/10.1002/jbmr.328

PMid:21337617

13. Grant WB, Holick MF. Benefits and requirements of Vitamin $D$ for optimal health: A review. Altern Med Rev. 2005;10(2):94-111. PMid:15989379

14. Baggerly CA, Cuomo RE, French CB, Garland CF, Gorham ED, Grant WB, et al. Sunlight and Vitamin D: Necessary for public health. J Am Coll Nutr. 2015;34(4):359-65.

PMid:26098394
15. Cannell JJ, Grant WB, Holick MF. Vitamin D and inflammation. Dermatoendocrinol. 2014;6(1):e983401.

PMid:26413186

16. Cannell JJ, Vieth R, Umhau JC, Holick MF, Grant WB, Madronich S, et al. Epidemic influenza and Vitamin D. Epidemiol Infect. 2006;134(6):129-40. https://doi.org/10.1017/ s0950268806007175

PMid:16959053

17. Evans LW, Omaye ST. Use of saliva biomarkers to monitor efficacy of Vitamin C in exercise-induced oxidative stress. Antioxidants (Basel). 2017;6(1):5. https://doi.org/10.3390/ antiox6010005

PMid:28085082

18. Rakshasbhuvankar AA, Clarke MW, Simmer K, Patole SK, Pillow JJ. Saliva for assessing Vitamin A status in extremely preterm infants: A diagnostic study. Neonatology. 2020;117(3):365-8. https://doi.org/10.1159/000506132 PMid:32114572

19. Annweiler C, Kabeshova A, Callens A, Paty ML, Duval GT, Holick MF. Self-administered Vitamin D status predictor: Older adults are able to use a self-questionnaire for evaluating their Vitamin D status. PLoS One. 2017;12(11):e0186578. https://doi. org/10.1371/journal.pone. 0186578

PMid:29091930

20. Biancuzzo RM, Clarke N, Reitz RE, Travison TG, Holick MF. Serum concentrations of 1,25-dihydroxyvitamin D2 and 1,25-dihydroxyvitamin D3 in response to Vitamin D2 and Vitamin D3 supplementation. J Clin Endocrinol Metab. 2013;98(3):9739. https://doi.org/10.1210/jc.2012-2114 PMid:23386645

21. Cocate PG, Kac G, Heitmann BL, Nadanovsky P, da Veiga Soares Carvalho MC, Benaim C, et al. Calcium and Vitamin D supplementation and/or periodontal therapy in the treatment of periodontitis among Brazilian pregnant women: Protocol of a feasibility randomised controlled trial (the IMPROVE trial). Pilot Feasibility Stud. 2019;5:38. https://doi.org/10.1186/ s40814-019-0417-6

PMid:30873290

22. Figueiredo $A C$, Trujillo J, Freitas-Vilela $A A$, Franco-Sena $A B$, Rebelo F, Cunha GM, et al. Association between plasma concentrations of Vitamin D metabolites and depressive symptoms throughout pregnancy in a prospective cohort of Brazilian women. J Psychiatr Res. 2017;95:1-8. https://doi. org/10.1016/j.jpsychires.2017.07.009 PMid:28755554

23. Isola G, Polizzi A, Muraglie S, Leonardi R, Giudice AL. Assessment of Vitamin $C$ and antioxidant profiles in saliva and serum in patients with periodontitis and ischemic heart disease. Nutrients. 2019;11(12):2956. https://doi.org/10.3390/ nu11122956

PMid:31817129

24. Balcells ME, García P, Tiznado C, Villarroel L, Scioscia N, Carvajal C, et al. Association of Vitamin D deficiency, season of the year, and latent tuberculosis infection among household contacts. PLoS One. 2017;12(4):e0175400. https://doi. org/10.1371/journal.pone. 0175400

PMid:28403225 